\section{Performance of Wheat Genotypes under Cadmium Contamination of Soil}

\author{
Adnan Rabnawaz', Zahid Akram*, Khalid Saifullah Khan² \\ and Qadeer Ahmad'
}

${ }^{1}$ Department of Plant Breeding and Genetics, University of Pir Mehr Ali Shah Arid Agriculture, Rawalpindi, Pakistan

${ }^{2}$ Department of Soil Science, University of Pir Mehr Ali Shah Arid Agriculture, Rawalpindi, Pakistan

\begin{abstract}
In order to evaluate different wheat genotypes against cadmium contamination of soil, an experiment was carried out in the department of Plant Breeding and Genetics, Pir Mehr Ali Shah-Arid Agriculture University Rawalpindi. The experiment was carried out under the control conditions. The experiment was laid out by using two factorial Completely Randomized Design (CRD) with six treatments and four replications. The treatments included six cadmium concentrations of cadmium in soil i.e., (control treatment, 5 ppm, 10 ppm, 15 ppm, $20 \mathrm{ppm}$ and $25 \mathrm{ppm}$ ). Parameters studied were germination $\%$ age, plant height $(\mathrm{cm})$, fresh shoot weight $(\mathrm{g})$, dry shoot weight $(\mathrm{g})$ and cadmium contents in shoot. The results showed the accumulation of cadmium in shoot of different wheat genotypes as compared to control treatment. Cadmium depicted the great variation as compared to control in different parameters studied.
\end{abstract}

Keywords: Accumulation; Cadmium concentration; Shoot; Uptake; Variation; Wheat genotypes

\section{Introduction}

Wheat (Triticumaestivum L.) is an important cereal crop of Pakistan. Wheat is the main crop produced in the country. It is used as the staple food and also used more as compared to any crop such as rice and maize [1]. Cadmium (Cd) is considered as the most toxic heavy metal as compared to other metals in soil which will ultimately reduce the plant growth and also affect some important characters of plants

*Corresponding author: Zahid Akram, Department of Plant Breeding and Genetics, University of Pir Mehr Ali Shah Arid Agriculture, Rawalpindi, Pakistan, Tel: +92 03075292949; E-mail: akramzahid@hotmail.com

Citation: Rabnawaz A, Akram Z, Khan KS, Ahmad Q (2017) Performance of Wheat Genotypes under Cadmium Contamination of Soil. J Plant Sci Curr Res 1: 003

Received: August 28, 2017; Accepted: December 19, 2017; Published: December 28, 2017

Copyright: () 2017 Rabnawaz A, et al. This is an open-access article distributed under the terms of the Creative Commons Attribution License, which permits unrestricted use, distribution, and reproduction in any medium, provided the original author and source are credited.
[2]. As its amount increases inside the soil, it will affect the overall crop production. Its addition in soil is due to water which is coming from our industries, metal mining, supply of fertilizer, and exploitation of pest control chemicals, seepage and dirt [3]. Cadmium pollutes the environment as well as it accumulates in grain of different crops and when man eats that food it causes different health problems more obvious are kidney, lungs and stomach problems. Cd has no significance for the functioning of crop plant but is much harmful to all the organisms in soil [4]. Maximum uptake of cadmium in wheat might be related to potash deficiency $[5,6]$. High mobility of this metal in soil-plant system allows its easy entry into the food chain where it may provoke both human diseases [7] and known toxic effects on animals, microorganisms and plants. Increasing international concern about the risks associated with long-term consumption of crops contaminated with $\mathrm{Cd}$ has led the international food standards organization, Codex Alimentarius commission, to propose a $0.1 \mathrm{mg} \mathrm{Cd}^{-\mathrm{kg}^{-1}}$ dry weight limit for cereals, pulses and legumes [8]. As this criterion may put under pressure the market of some agricultural products, several strategies have been proposed for the successful management of the Cd-contaminated agricultural soils. One approach is aiming to screen and use low Cd-accumulating genotypes of crops, known to accumulate unacceptable high $\mathrm{Cd}$ levels in grain [9]. The second approach recommends profitable use of both non-food crops and cereals for seed production $[10,11]$. The third option is metal phytoextraction, based on the natural or "induced" ability of plants Cd phytoextraction 70 to uptake metals (and organics) from soil and to concentrate them in the harvestable parts $[12,13]$. Movement of Cd from roots to shoots is a critical point for $\mathrm{Cd}$ phytoextraction. To be able to reach xylem vessels, metal uptake is taking place at the younger parts of the root, where Casparian strips are not well developed [14]. The absorbed metals are unloaded from the xylem parenchyma into mature xylem vessels, but this process is not well understood [15]. There is some evidence for elevated loading rates for some metals in hyper accumulator plants: $\mathrm{Zn}$ in Thlaspi caerulescens [16] and $\mathrm{Ni}$ in Alyssum lesbiacum [15], but no information is available for Cd. Regarding the significance of cadmium on plant fate and its crucial effect on the health of humans, the present study was designed with the objective to sort out different wheat genotypes which can be utilized to reduce cadmium contamination of soil.

\section{Materials and Methods}

The experimental material consisted of 20 wheat genotypes. These genotypes were obtained from Plant Genetic Resources Institute (PGRI), National Agricultural Research Centre (NARC), and Islamabad. Sowing was done in the research area of Pir Mehr Ali Shah- Arid Agriculture University Rawalpindi, during October, 2011. These genotypes were sown in small pots, each pot having $375 \mathrm{~g}$ of soil using the electric balance. Completely Randomized Design (CRD) was used with four replications at different levels of cadmium concentrations (control, 5 ppm, 10 ppm, 15 ppm, 20 ppm, and 25 $\mathrm{ppm}$ ). Parameters recorded in this study were germination percentage, plant height, fresh shoot weight, and dry shoot weight and cadmium contents in shoot. Germination percentage was taken after 30 days of sowing by dividing total number of seedling emerged over the 
total number of seeds sown. Plant height was calculated in centimeters from base to top where spike emergence took place. For fresh shoot weight, plants were separated from the soil washed with water and shoot was cleaned with the help of tissue to avoid moisture and then shoot was weighed by using digital balancer to avoid the dryness of shoots. Dry shoot weight was taken by placing the shoots in oven for three days at $70^{\circ} \mathrm{C}$, after that shoots were taken off from oven and placed into desiccator to avoid moisture for further analysis. Cadmium in shoots was recorded by using the atomic absorption spectrophotometer (Model GBC-932 Plus). About $0.5 \mathrm{~g}$ of plant ground material was taken into digestion tube and $4.4 \mathrm{ml}$ of digestion blend was added to each tube. Digestion was done at $350^{\circ} \mathrm{C}$ for 2 hours. After this, all solution became color less and remaining solid turned into white color. First, there was no color change, so solution was further heated for 1 hour to change the color. Based on the data recorded, three promising wheat genotypes were selected which were further used in the second experiment.

\section{Statistical analysis}

Data were subjected to ANOVA (Analysis of Variance) technique and means were compared by LSD test following [17].

\section{Results and Discussion}

\section{Germination percentage}

The results of germination percentage are shown in table 1 . The maximum germination was found at treatment $\mathrm{T}_{3}, 98 \%$ followed by $97 \%$ at treatment $T_{4}$. Minimum germination was found in treatment $\mathrm{T}_{5}$ which was $87 \%$. Our findings depicted the variable amount of germination percentage at different cadmium levels. This might be due to genotypic or geographic differences such as control showing more germination as compared to treatment $\mathrm{T}_{5}$ but the control showing less germination as compared to $T_{2}, T_{3}$ and $T_{4}$ respectively. Variation in seed germination of different cultivars against $\mathrm{Cd}$ stress might have been due to presence of genetic diversity in the cultivars used in the study. Such kind of response has also been reported by Zhang et al., [18]. The findings of present study revealed that $20 \mathrm{ppm}$ must be the maximum limit for $\mathrm{Cd}$ but treatment $\mathrm{T}_{4}(97 \%)$ showed that there was less effect of $\mathrm{Cd}$ due to variation in genotypes. Due to genetic and environmental variations some genotypes performed best and others performed not well as compared to control $\mathrm{T}_{0}$.

\begin{tabular}{|c|c|c|c|c|c|}
\hline $\begin{array}{c}\mathbf{T}_{\mathbf{0}} \\
\text { (Control) }\end{array}$ & $\begin{array}{c}\mathbf{T}_{1} \\
(\mathbf{5} \mathbf{~ p p m})\end{array}$ & $\begin{array}{c}\mathbf{T}_{2} \\
(\mathbf{1 0} \mathbf{p p m})\end{array}$ & $\begin{array}{c}\mathbf{T}_{3} \\
(\mathbf{1 5} \mathbf{~ p p m})\end{array}$ & $\begin{array}{c}\mathbf{T}_{4} \\
(\mathbf{2 0} \mathbf{~ p p m})\end{array}$ & $\begin{array}{c}\mathbf{T}_{5} \\
(\mathbf{2 5} \mathbf{p p m})\end{array}$ \\
\hline $90 \%$ & $96 \%$ & $94 \%$ & $98 \%$ & $97 \%$ & $87 \%$ \\
\hline
\end{tabular}

Table 1: Germination percentage at different cadmium amounts.

\section{Effect of cadmium on fresh, shoot weight}

Shoot fresh weight data is shown in table 2. There was a difference among the genotypes and treatment means studied. Among different genotypes, maximum fresh shoot weight was found in genotype (018702) 0.2113 followed by (018702) 0.21g, (018691) $0.197 \mathrm{~g}$ and 018681 (0.197), respectively. Minimum fresh shoot weight was observed in genotype (018683) $0.145 \mathrm{~g}$, (018688) 0.1472 and (018675) $0.1475 \mathrm{~g}$, respectively. Maximum fresh shoot weight was found at treatment $T_{1}(0.193)$. Minimum fresh shoot weight was recorded in $\mathrm{T}_{5}$ (0.156). Mean fresh shoot weight in genotypes under Cd treatment decreased $44.7 \%$ in comparison with control. Treatment means are shown in figure 2. Bhardwaj et al., [20] in their study on beans found that if Cadmium content is increased $1.5,2.0,2.5,3.0 \mathrm{~g} \mathrm{Kg}^{-1}$ it resulted in a decrease in total weight and shoot fresh weight of young seedlings. Khadijeh et al., [21] also reported that if we increase the cadmium level it would ultimately reduce the fresh shoot weight of seedlings. Presence of cadmium activity can lead to reduction in yield ultimately.

\begin{tabular}{|c|c|c|c|c|c|}
\hline S. No. & Wheat Genotypes & Plant Height (cm) & Fresh Shoot Weight (g) & Dry Shoot Weight(g) & Cadmium (ppm) \\
\hline 1 & 18674 & $15.767 \mathrm{~A}$ & $0.2113 \mathrm{~A}$ & $0.2113 \mathrm{~A}$ & $5.6667 \mathrm{~A}$ \\
\hline 2 & 18679 & $15.608 \mathrm{AB}$ & $0.2104 \mathrm{AB}$ & $0.2104 \mathrm{AB}$ & $5.5208 \mathrm{~B}$ \\
\hline 3 & 18680 & $15.412 \mathrm{AB}$ & $0.1979 \mathrm{ABC}$ & $0.1979 \mathrm{ABC}$ & $5.4833 \mathrm{BC}$ \\
\hline 4 & 18685 & $15.275 \mathrm{ABC}$ & $0.1906 \mathrm{ABCD}$ & $0.1906 \mathrm{ABCD}$ & $5.5042 \mathrm{BC}$ \\
\hline 5 & 18678 & $15.267 \mathrm{ABC}$ & $0.1882 \mathrm{ABCDE}$ & $0.1882 \mathrm{ABCDE}$ & $5.4833 \mathrm{BC}$ \\
\hline 6 & 18684 & $15.160 \mathrm{ABC}$ & $0.1827 \mathrm{ABCDEF}$ & $0.1827 \mathrm{ABCDEF}$ & $5.4792 \mathrm{BC}$ \\
\hline 7 & 18686 & $15.129 \mathrm{ABCD}$ & $0.1816 \mathrm{ABCDEF}$ & $0.1816 \mathrm{ABCDEF}$ & $5.4750 \mathrm{BC}$ \\
\hline 8 & 18675 & $15.087 \mathrm{ABCD}$ & $0.1775 \mathrm{ABCDEF}$ & $0.1775 \mathrm{ABCDEF}$ & $5.4708 \mathrm{BC}$ \\
\hline 9 & 18682 & $14.921 \mathrm{ABCD}$ & $0.1716 \mathrm{ABCDEF}$ & $0.1716 \mathrm{ABCDEF}$ & $5.4708 \mathrm{BC}$ \\
\hline 10 & 18702 & $14.892 \mathrm{ABCD}$ & $0.1715 \mathrm{ABCDEF}$ & $0.1715 \mathrm{ABCDEF}$ & $5.4708 \mathrm{BC}$ \\
\hline 11 & 18677 & $14.825 \mathrm{ABCD}$ & $0.1710 \mathrm{BCDEF}$ & $0.1710 \mathrm{BCDEF}$ & $5.4708 \mathrm{BC}$ \\
\hline 12 & 18691 & $14.742 \mathrm{ABCD}$ & $0.1707 \mathrm{BCDEF}$ & $0.1707 \mathrm{BCDEF}$ & $5.4667 \mathrm{BC}$ \\
\hline 13 & 18703 & $14.329 \mathrm{ABCD}$ & $0.1697 \mathrm{CDEF}$ & $0.1697 \mathrm{CDEF}$ & $5.4625 \mathrm{BC}$ \\
\hline 14 & 18681 & $14.050 \mathrm{BCD}$ & $0.1644 \mathrm{CDEF}$ & $0.1644 \mathrm{CDEF}$ & $5.4500 \mathrm{BC}$ \\
\hline 15 & 18676 & $13.642 \mathrm{CD}$ & $0.1585 \mathrm{CDEF}$ & $0.1585 \mathrm{CDEF}$ & $5.4500 \mathrm{BC}$ \\
\hline 16 & 18687 & $13.442 \mathrm{D}$ & $0.1516 \mathrm{DEF}$ & $0.1516 \mathrm{DEF}$ & $5.4458 \mathrm{BC}$ \\
\hline 17 & 18689 & $11.675 \mathrm{E}$ & $0.1495 \mathrm{EF}$ & $0.1495 \mathrm{EF}$ & $5.4333 \mathrm{BC}$ \\
\hline 18 & 18683 & $11.387 \mathrm{E}$ & $0.1475 \mathrm{~F}$ & $0.1475 \mathrm{~F}$ & $4.7333 \mathrm{C}^{*}$ \\
\hline 19 & 18692 & $11.375 \mathrm{E}$ & $0.1472 \mathrm{~F}$ & $0.1472 \mathrm{~F}$ & $4.2417 \mathrm{D}^{*}$ \\
\hline 20 & 18688 & $11.350 \mathrm{E}$ & $0.1449 \mathrm{~F}$ & $0.1449 \mathrm{~F}$ & $4.1458 \mathrm{E}^{*}$ \\
\hline
\end{tabular}

Table 2: Treatment Mean of different parameters of 20 wheat genotypes used in the study. 


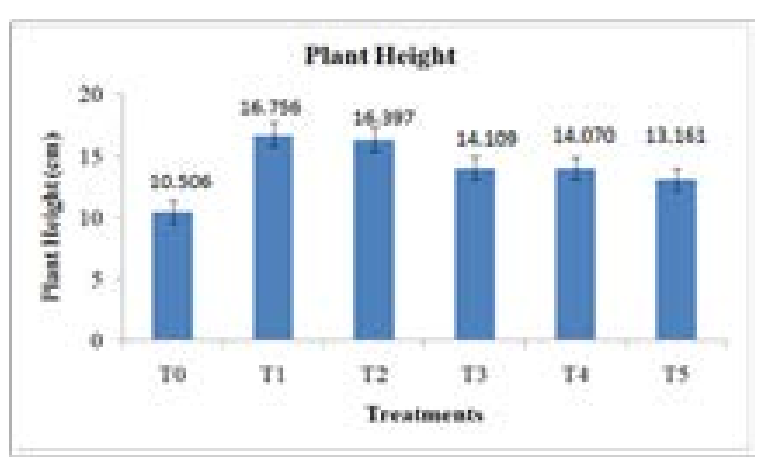

Figure 1: Bars graph showing the treatment mean for plant height.

\section{Effect of cadmium on fresh, shoot weight}

Shoot fresh weight data is shown in table 2 . There was a difference among the genotypes and treatment means studied. Among different genotypes, maximum fresh shoot weight was found in genotype (018702) 0.2113 followed by (018702) $0.21 \mathrm{~g}$, (018691) $0.197 \mathrm{~g}$ and 018681 (0.197), respectively. Minimum fresh shoot weight was observed in genotype (018683) $0.145 \mathrm{~g}$, (018688) 0.1472 and (018675) $0.1475 \mathrm{~g}$, respectively. Maximum fresh shoot weight was found at treatment $T_{1}(0.193)$. Minimum fresh shoot weight was recorded in $\mathrm{T}_{5}$ (0.156). Mean fresh shoot weight in genotypes under Cd treatment decreased $44.7 \%$ in comparison with control. Treatment means are shown in figure 2. Bhardwaj et al., [20] in their study on beans found that if Cadmium content is increased $1.5,2.0,2.5,3.0 \mathrm{~g} \mathrm{~kg}^{-1}$ it resulted in a decrease in total weight and shoot fresh weight of young seedlings. Khadijeh et al., [21] also reported that if we increase the cadmium level it would ultimately reduce the fresh shoot weight of seedlings. Presence of cadmium activity can lead to reduction in yield ultimately.

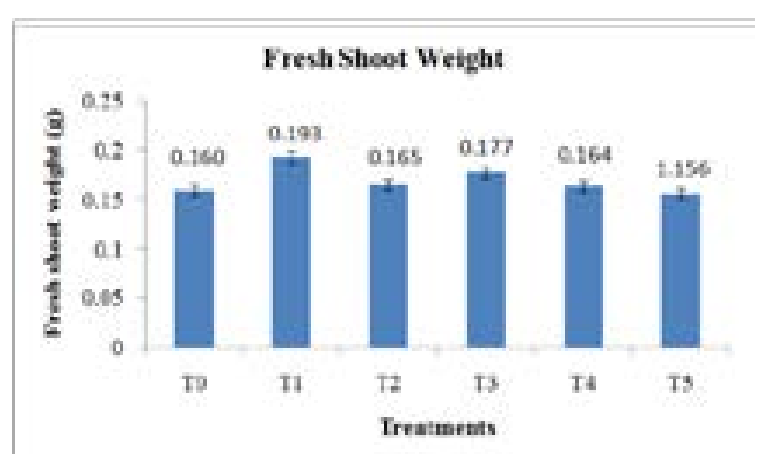

Figure 2: Bars graph showing the treatment mean for fresh shoot weight.

\section{Effect of cadmium on dry shoot weight}

The calculated means regarding dry shoot weight observed are presented in table 2 . The data revealed that there was a significant difference among the genotypic means studied. The maximum dry shoot weight was found by the genotype (018681) $0.0372 \mathrm{~g}$ closely followed by (018683) $0.0366 \mathrm{~g}$, (018677) $0.0340 \mathrm{~g}$ and $(018680)$ $0.0339 \mathrm{~g}$, respectively. 0 . Minimum dry shoot weight was observed in genotype V20 (018703) 0271g followed by genotype (018692) $0.0274 \mathrm{~g}$ and $(018688) 0.0276 \mathrm{~g}$, respectively. Treatment means are elaborated in figure 3. Maximum dry shoot weight was found at treatment T1 (0.036). Minimum dry shoot weight was recorded at treatment T4 (0.029). Khadijeh et al., [21] reported that dry shoot weight is decreased with the increase in cadmium concentrations.

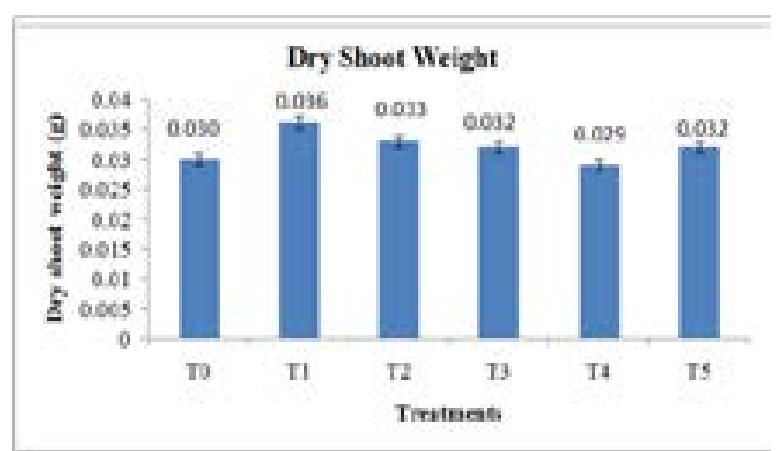

Figure 3: Bars graph showing the treatment mean for dry shoot weight.

\section{Cadmium content in shoot}

Data regarding cadmium content in shoot is presented in table 2. It revealed that interaction between the genotypes and treatment was highly significant. However, a difference was found in means of all the genotypes used in the study. Three genotypes were screened against the cadmium contamination of soil. Treatment means are shown in figure 4. Maximum cadmium uptake was found in wheat genotype (018675) $5.67 \mathrm{mg} \mathrm{kg}^{-1}$ and (018681) $5.52 \mathrm{mg} \mathrm{kg}^{-1}$. Minimum cadmium uptake was recorded in genotype (018674) with the mean of ( $\left.4.14 \mathrm{mg} \mathrm{kg}^{-1}\right)$ followed by genotype (018680) with the mean of $4.24 \mathrm{mg} \mathrm{kg}^{-1}$ and genotype (018676) with the mean of $(4.73 \mathrm{mg}$ $\left.\mathrm{kg}^{-1}\right)$. Maximum cadmium uptake was recorded at treatment $T_{5}(10.7$ $\left.\mathrm{mg} \mathrm{kg}^{-1}\right)$ followed by treatment $\mathrm{T}_{4}\left(8.37 \mathrm{mg} \mathrm{kg}^{-1}\right)$. Minimum cadmium uptake was recorded at treatment $\mathrm{T}_{1}$ control $(0.00)$ followed by $\mathrm{T}_{2}$ $\left(2.27 \mathrm{mg} \mathrm{kg}^{-1}\right)$. Brookes PC [22] described that as we increase the amount of cadmium, plants showed more cadmium uptake.

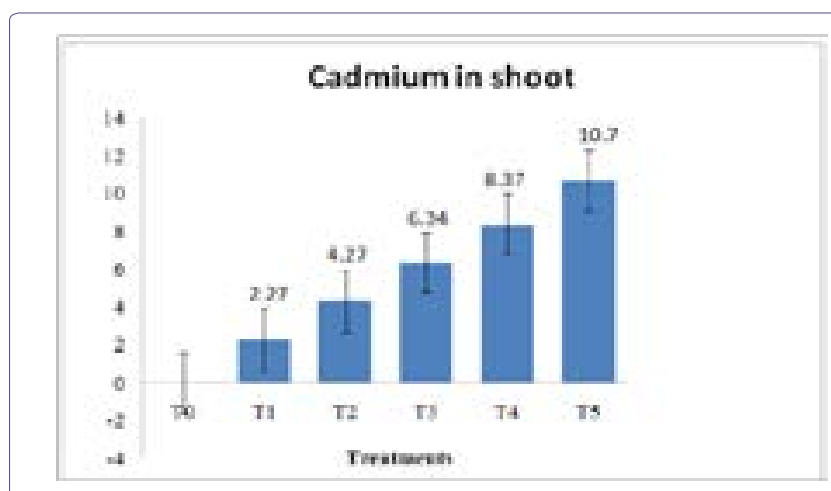

Figure 4: Bars graph showing the treatment mean for cadmium uptake.

\section{Conclusion}

The present study indicated that different plant traits performed different in different concentration of Cadmium content. Maximum 
cadmium uptake was found in wheat genotype (018675) $5.67 \mathrm{mg} \mathrm{kg-1}$ and (018681) $5.52 \mathrm{mg} \mathrm{kg-1}$ and minimum cadmium uptake was recorded in genotype (018674) with the mean of (4.14 mg kg-1). The maximum dry shoot weight was shown by the genotype (018681) $0.0372 \mathrm{~g}$ and minimum dry shoot weight was observed in genotype (018703) 0.0271g. Maximum fresh shoot weight was found in genotype (018702) $0.2113 \mathrm{~g}$ and minimum fresh shoot weight was observed in genotype (018683) $0.145 \mathrm{~g}$. Maximum plant height $(\mathrm{cm})$ was observed in genotype (018674) $15.767 \mathrm{~cm}$ and minimum plant height $(\mathrm{cm})$ was seen in genotype $(018688) 11.350 \mathrm{~cm}$. It is concluded that promising genotypes that performed best in the presence of cadmium content can be used for further breeding program.

\section{References}

1. Bakhsh A, Hussian A, Khan AS (2003) Genetic studies of plant height, yield and its components in bread wheat. Sarhad journal of agriculture 19: 529-534.

2. Sanità di Toppi L, Gabrriel R (1999) Response to cadmium in higher plants. Environmental and Experimental botany 41: 105-130.

3. Angelova I, Atanassov VI (1999) Deposition of $\mathrm{Pb}, \mathrm{Zn}, \mathrm{Cd}$ and $\mathrm{Cu}$ in the soil in the soil of the smelters areas near Plovdiv. Sci WorkWorks Higher Ins 38: 99-102.

4. Alloway BJ (1995) Heavy metals in soils. Springer Science \& Business Media, Berlin, Germany.

5. Grahame RD, Ascher JS, Hynes SC (1992) Selecting zinc efficient cereals genotypes for soils of low zinc status. Plant and Soil 146: 241-250.

6. Cakmaak I, Torun B, Erenoglu B, Ozturk L, Marschner H, et al. (1998) Morpholigical differences in cereals in response to zinc deficiency. Euphytica 100: 349-357.

7. Nogawa K, Honda R, Kido T, Tsuritani I, Yamada Y (1987) Limits to protect people eating cadmium in rice, based on epidemiological studies. Trace substances in environmental health 21: 431-439.

8. Harris NS, Taylor GJ (2001) Remobilization of cadmium in maturing shoots of near isogenic lines of durum wheat that differ in grain cadmium accumulation. J Exp Bot 52: 1473-1481.

9. Archambault DJ, Marentes E, Buckley W, Clarke J, Taylor GJ (2001) A rapid seedling-based bioassay for identifying low cadmium-accumulating individuals of durum wheat (Triticum turgidum L.). Euphytica 117: 175182.
10. Zheljazkov V, Nielsen N (1996) Effect of heavy metals on pepper mint and cornmint. Plant and Soil 178: 59-66.

11. Vassilev A, Kerin V, Atanassov P (1996) Effect of cadmium pollution of soil upon productivity and seedling qualities of two barley (H. vulgare L.) cultivars. Bulgarian Journal of Agricultural Science 2: 333-340.

12. Salt DE, Smith RD, Raskin I (1998) Phytoremediation. Annu Rev Plant Physiol Plant Mol Biol 49: 643-668.

13. Robinson BH, Leblanc M, Petit D, Brooks RR, Kirkman JH, et al. (1998) The potential of Thlaspi caerulescens for phytoremediation of contaminated soils. Plant and Soil 203: 47-56.

14. Hardiman RT, Jacoby B (1984) Absorption and translocation of Cd in bush beans (Phaselous vulgaris). Physiologia Plantarum 61: 670-674.

15. Salt DE, Kramer U (2000) Mechanism of metal hyper accumulation in plants. In: Phytoremediation of toxic metals: Using plants to clean up the environment. John Wiley and Sons, New York, USA.

16. Lasat MM, Baker AJ, Kochian LV (1998) Altered Zn compartmentation in the root symplasm and stimulated $\mathrm{Zn}$ absorption into the leaf as mechanisms involved in $\mathrm{Zn}$ hyperaccumulation in Thlaspi caerulescens. Plant Physiol 118: 875-883.

17. Steel RGD, Torrie JH, Dickey DA (1997) Principles and procedures of statistics: A biometrical approach, ( $3^{\text {rd }}$ edn). McGraw Hill, New York, USA. Pg no: 400- 428 .

18. Zhang S, Hu J, Chen ZH, Chen JF, Zheng YY, et al. (2005) Effects of Pb pollution on seed vigour of three rice varieties. Rice Science 12: 197-202.

19. Zhou W, Qiu B (2005) Effects of cadmium hyper accumulation on physiological characteristics of Sedum alfredii Hance (Crassulaceae). Plant Science 169: 737-745.

20. Bhardwaj P, Chaturvedi AK, Prasad P (2009) Effect of enhanced lead and cadmium in soil on physiological and biochemical attributes of Phaselous vulgaris L. Nature and Science 7: 63-75.

21. Khadijeh B, Kholdebarin B, Moradshahi A (2011) Effect of cadmium on growth, protein content and speroxidase activity in pea plants. Pak J Bot 43: $1467-1470$

22. Brookes PC (1995) The use of microbial parameters in monitoring soil pollution by heavy metals. Biology and Fertility of Soils 19: 269-279. 